\title{
Increasing the Efficiency of State Institutional Aid to Small Innovative Enterprises
}

\author{
Sergey Mikhailovich Vasin ${ }^{1} \&$ Leyla Ayvarovna Gamidullaeva ${ }^{1}$ \\ ${ }^{1}$ Department of Economics and Management, Penza State University, Penza, Russia \\ Correspondence: Sergey Mikhailovich Vasin, Department of Economics and Management, Penza, 440026, \\ Russia. Tel: 8-937-400-2434. E-mail: pspu-met@mail.ru
}

Received: April 11, 2015 Accepted: May 3, $2015 \quad$ Online Published: June 26, 2015

doi:10.5539/res.v7n11p77 URL: http://dx.doi.org/10.5539/res.v7n11p77

\begin{abstract}
This article is devoted to solving the urgent problem of low efficiency of state support system for small innovative enterprises. The development of this sector is essential for the future of Russian economy. The recent economic crisis has only reinvigorated the debate. In generally our paper is concerned with studying the specific factors that influenced a behavior of small enterprises to be involved in innovation process. This paper elaborates a methodological approach for systematically identifying and estimating institutional factors in the system of small innovative business. The authors have developed a method for assessing the effectiveness of state support system at the regional level, which makes it possible to evaluate an actual level of performance management in a particular region and to identify existing reserves. Correlation and regression analysis, which allows identifying the most important factors that have the greatest influence on the efficiency of state support system in the sector, were conducted. In addition, proposed correlation and regression models are developed. Application of this method in practice of public administration will take into account the influence of qualitative factors in evaluating the effectiveness of support system for small enterprises as a whole.
\end{abstract}

Keywords: state support, methodical approach, innovative entrepreneurship

\section{Introduction}

In modern conditions, a set of leading countries in terms of economic development has already formed. Moreover, Russia is largely lags behind of them. This fact makes it necessary to conduct an urgent modernization and build an innovative economy (Gamidullaeva, 2014).

The state, its federal and regional authorities are called to create favorable economic, political, social, and legal conditions for the formation of the economic mechanism that would facilitate the development of small innovative entrepreneurship, entrepreneurial type of reproduction processes, stability of the entire economic system.

Adverse economic conditions in which a development of small innovative business takes place, largely due to problems related to the lack of development of mechanisms for the implementation of laws, regulations governing the development of entrepreneurship. This fact makes it very difficult and even impossible the direct use of models of development and support of small innovative business, successfully implemented in several developed countries.

According to experts, in the industrialized countries more than $75-80 \%$ of Gross domestic product are achieved by innovation. Moreover, for the leading countries in the market of innovation there is a certain regularity, which contains the priority role of small innovative businesses in the economy of these countries.

In Russia, the level of development of small innovative enterprises is much lower. Its share in the structure of small business is insignificant and is variously estimated from $1.4 \%$ to $3.5 \%$.

In recent years the innovative activity of enterprises in Russia on average has showed a negative trend (decreased from the level of $9.9 \%$ in 2006 to $9.5 \%$ in 2013). At the same time, the situation at the regional level is significantly different. Analyzing the situation in the regions, we conclude that there is no direct connection between aforementioned indicator and the volume allocated in the region financial resources to support the field of innovative entrepreneurship. 
In our opinion, in general, significant variation indicator of innovative activity of small businesses in the regions is due to different levels of effectiveness of institutional state support in this area.

State aid is a complicated phenomenon that may have several aims. The effects of this aid may also be varied and difficult described by a single indicator. However in our study, we focused on the effects of the state aid as the growth of small businesses (SE) in general and the growth of innovative enterprises.

An important aim is to estimate how regional institutions of support affect the innovation activity of the system's actors and in what directions regional policy are able to contribute to formation needful conditions.

The business environment determines efficiency of small entrepreneurship. For this reason clearly defined property rights, effective institution work, information availability etc. all increase firm efficiency.

The business environment contains cultural, demographic, political, economic, social and technological factors and natural resources that deviate between countries. It is quite obvious that in transition economies, the main problems in development entrepreneurship can be obtained from the cultural background and a non-existent entrepreneurial heritage. However, during the transformation period, a lot of capacity can be created for opportunity development. There may be a hidden innovation and growth potential in existing firms that can be unleashed by introducing incentives and initiatives to improve business skills and know-how, increase entrepreneurial spirit, and promote an expansion mentality and an entrepreneurial culture. However, such efforts should not focus solely on innovations and growth. The diversity of local firms and the jobs they create should be appreciated, too (Stark \& Brown, 1997).

Institutions (rules, routines, traditions, conventions etc.) by being internalized by the most of SMEs contribute both to ensure the stability in socio-economic sphere and to shaping evolutionary economic trajectories (North, 1990; Maskell \& Malmberg, 1999; Scott, 1995).

The economic literature has extensively discussed the problem about SMEs needs in comparison with large firms (see among others Avery et al., 1998; Berger \& Udell, 1998; Gregory et al., 2005). SME financing is generally characterised by higher transaction costs for a few reasons: organisational features and business strategies generally do not allow them to contact with the external business environment in the same transparent way that a firm accessing state financing would require. Unlike of large-size enterprises, SME's business plans and strategies are rarely mentioned in the press or publicly disclosed.

According to the recent researches (Justman and Teubal, 1996) the infrastructural conditions may take up a central role in process of increasing of innovative activity of SMEs. Clearly that many of the policy measures have a link with a new concept of Technological Infrastructure including scientific and technological parks and the research institutes, which act as catalysts of knowledge and incubators for new types of entrepreneurship.

It should be noted that the effectiveness of state support in the domestic economy is mentioned in the works of Dadashov and Baranova (2009), Savanovich (2009), Garifullina (2014), Kalmikova et al. (2014), Lukyanova and Avanesova (2011), etc.

In the study of Generalov and Lychagin (2004) the focus is on detailed analysis procedure of government support programs, including an assessment of their effectiveness.

Among the works devoted to the foreign experience of state regulation and support of entrepreneurship, contributions of Hübner (1996), Norrman and Bager-Sjogren (2010), Mcmahon (1990), Fuller (2005) should be mentioned.

However, most researchers consider the problem only from the perspective of state regulation of small innovative enterprises, although it is nowadays necessary to create an integrated system of support for this sector of the state. The problem of creating the infrastructure elements of such a system in most studies is solved exclusively with organizational and technological aspects, but the support system that should not be limited. Due to its support the possible involvement in the process of real economic reserves of small innovative businesses, enhance the dynamics and social orientation of economic development of Russia.

There are no enough scientific studies which allow to describe an integrated approach to the evaluation of efficiency of the system of state support for SEs. Only certain components of this system are estimated in the papers of some authors and this does not take into account the impact of other factors on the effective functioning of the system, thus hampering the selection and adoption of the best managerial decisions.

This article focuses on solving important scientific problems consisting in improving governance through the elaborating methodology for assessing the effectiveness of public support for SE sector. This will allow to systematically identify existing reserves to manage and build effective administrative action. 


\section{Materials and Method}

The definition of SE means that small enterprise is an enterprise that satisfies all of the following criteria firstly, has fewer than 100 employers and secondly, has either the sum of proceeds from the sale of goods and services not exceeding 400 million rubles.

The present study of the effectiveness of state aid to SEs was conducted in several stages.

At the first stage the preparation for the study has been made: the definition of goals and objectives of the study, interpretation of the basic concepts, systematic analysis of the research subject, the definition of procedures for the collection and analysis of primary data.

In the second stage methods and research tools were developed.

In the third stage a study of efficiency of state support for the small innovative enterprises was obtained in the Russian regions by surveying managers of SEs.

The fourth stage included the creation of the dataset, the calculation based on their performance indicators of the effectiveness of state support to SEs, development and justification of correlation-regression models describing the influence of individual performance indicators of state aid to SEs on indicators characterizing the development of SEs in regions.

The fifth and final stage of the study included the analysis and interpretation of the results, the formulation of conclusions and recommendations.

The program of sampling included:

1) Delimitation of the general population

2) Determination the minimum sample size with a predetermined level of confidence

3) Determination of the type of sample survey

4) Establishing the timing of the survey

5) Analysis of the results.

A small innovative enterprise was defined as a unit of selection to ensure homogeneity of sample.

It is traditionally measured by following indicator: enterprises engaged in technological innovation as a per cent of enterprises total. Data for these indicators was obtained from Russian Federal State Statistics Service. Thus, in 2013 the total sample of our study was 736490 businesses.

The term of technological innovation according to Rosstat's methodological notes can be defined as organization's activities related implementation of new or implementation of:

- Technologically new products and processes, as well as significant technological improvements in products and processes;

- Technological improvements in products and processes;

- Technologically new or significantly improved services;

- New or significantly improved production methods of services.

We have chosen a $95 \%$ confidence level, 0.5 standard deviation, and a margin of error (confidence interval) of $+/-5 \%$.

Necessary Sample Size $=(Z \text {-score })^{2} * \operatorname{StdDev} *(1-\operatorname{StdDev}) /(\text { margin of error })^{2}$.

Our sample comprises 385 SEs from the different regions of Russian Federation. A questionnaire survey was conducted in 14 regions including Kaluga region, Moscow, Tambov, Rostov region, Republic of Dagestan, Republic of Tatarstan, Penza region, Krasnoyarsk region, Republic of Mordovia, Samara region, Chuvashia, Chelyabinsk and Sverdlovsk region, Tomsk region, among the heads and the clients of business incubators small innovative enterprises.

Consequently, the sample is representative and the results of the study can be transferred to the general set, that is, small innovative entrepreneurship of Russia.

Since SEs heads were interviewed not only as a source of information on the actual situation of their business, but also as experts evaluating the effectiveness of state aid sector for small innovative businesses. The experts were also directors of large, medium and small enterprises, the heads of higher education institutions, business-incubators and technoparks. 
It was necessary to assess their reliability and calculate the corresponding coefficients. The number of experts corresponds to a small sample of experts Students. The average coefficient of congruence experts is 0.72 . The average coefficient of argumentation for all experts is 0.85 , which indicates a high degree of reasoning. Level of competence of the expert group was 0.785, which corresponds to an above - average level (Gromova, 2006).

System of state management of innovation projects of SEs can be described as a set of quantitative and qualitative indicators, the degree of influence on the performance of the sector SE is often undervalued. This study developed indicators to measure the effectiveness of certain types of state support.

The evaluation of these parameters is of great significance, since it is possible to determine the basis of the reserves in the management and improve the effectiveness of state aid system.

Formation of indicators`aggregate for assessing state aid of SE's system has been performed according to the following principles:

1) Each of the subsystems of state support system of SE should be fully covered by indicators.

2) Indicators that reflect the sequence of management actions shall be designed within each subsystem.

3) When calculating the indicators it is necessary to combine (if possible) several analytical techniques that help to reflect the actual and the desired state of a management event.

4) Efficiency indicators should be calculated with the greatest possible accuracy.

The evaluation of these parameters is of great importance, since on its basis it is possible to determine the level of those or other management activities. Based on which it is possible to reveal reserves in the management and improve the effectiveness of state support system for SE.

Approaches to the calculation of indicators that reflect the level of any management activities are slightly different depending on the research methods used in the analysis of specific activities.

Calculation of the first group of indicators is the result of a combination of several methods, which includes the method of questioning and the expert-analytical one. The scale of assessment of an indicator in this case is formulated to carry out a comparison of estimates of actual use criteria, directions and other methodological components of the system of state support of SEs and their expected effectiveness, the importance from the viewpoint of business executives and government agencies (as determined by the results of the expert survey). Directions was evaluated in fractions of a unit in the range from 0 to 1 , with a gradation into six main states: a complete lack or insignificance of a certain criterion (0), a very small degree of use or efficiency $(0-0.2)$, rather insignificant level (0.21-0.4), the average level (0.41-0.6), greater level (0.61-0.8), a very high level (0.81-1.0) of the actual application and effectiveness.

The second group of indicators calculated on the basis of data obtained from the Federal State Statistics Service.

Considering more detail the calculation of the proposed indicators it is possible to measure the effectiveness of our state support for SE.

Performance indicator of the state information support of SE:

$$
I_{\text {inf }}=\sum\left(I_{\text {act }} * I_{\text {imp }}\right) \text {, }
$$

where

$I_{\text {act }}$ - the actual level of development of each direction of information support;

$I_{\text {imp }}$ - expert assessment of the importance of each direction of information support.

Similarly, the following parameters were calculated:

- An indicator of the availability of the existing state support programs (in terms of the established criteria for selecting businesses to participate in them);

- An indicator of the availability of innovative infrastructure;

- An indicator of the effectiveness of service delivery innovation infrastructure;

- An indicator of the effectiveness of personnel support;

- An indicator of the effectiveness of expert and consulting support;

- An indicator of the effectiveness of scientific support;

- An indicator of the effectiveness of financial and credit support.

The outcome indicators of effectiveness of state support for SEs surveyed regions are presented in Tab. 1 . 
Table 1. The outcome indicators of effectiveness of state support for SEs

\begin{tabular}{|c|c|c|c|}
\hline No. & Regions & $\begin{array}{l}\text { Innovative activity of organizations } \\
\text { (percent) at the end of } 2013 \text { year } \\
\text { (Federal State Statistics). }\end{array}$ & $\begin{array}{l}\text { Number of registered small businesses } \\
\text { on October } 1,2013 \text {, per } 100 \text { thousand } \\
\text { inhabitants of the region (Calculated by } \\
\text { the authors based on the data of Federal } \\
\text { State Statistics). }\end{array}$ \\
\hline 1 & Kaluga region & 10.9 & 187.2 \\
\hline 2 & Moscow region & 8.4 & 153.8 \\
\hline 3 & Tambov region & 9.2 & 187.4 \\
\hline 4 & Rostov region & 7.7 & 183.5 \\
\hline 5 & $\begin{array}{l}\text { Republic } \\
\text { Dagestan }\end{array}$ & 10.3 & 22.6 \\
\hline 6 & Republic of Tatarstan & 21.0 & 32.2 \\
\hline 7 & Penza region & 15.6 & 167.0 \\
\hline 8 & Krasnoyarsk region & 11.2 & 135.5 \\
\hline 9 & $\begin{array}{l}\text { Republic } \\
\text { Mordovia }\end{array}$ & 16.9 & 115.1 \\
\hline 10 & Samara region & 5.4 & 123.8 \\
\hline 11 & Chuvashia & 18.8 & 196.9 \\
\hline 11 & Chelyabinsk region & 9.8 & 0.0 \\
\hline 13 & Sverdlovsk region & 11.5 & 174.3 \\
\hline 14 & Tomsk region & 14.6 & 150.1 \\
\hline
\end{tabular}

As a demonstration sequence of the study we submit the analysis of performance indicator of the state information support for the SE. Based on an expert survey provided estimates of the importance of each direction of information support, where, firstly, the index is directly calculated, and secondly, it is provides the possibility of comparing the actual and the indicator to calculate the maximum possible value of this indicator. In the theoretical assumption of the highest level of development in each direction information support this indicator takes the theoretically maximum possible value of $18.91(3,782 * 5)$. Calculating the indicator for each region, we are able to compare the development of management activities in the field of information support SE to the maximum possible value, and relatively to each other, and simultaneously to formulate definite conclusions about the presence of reserves in the management (Fig. 1). 


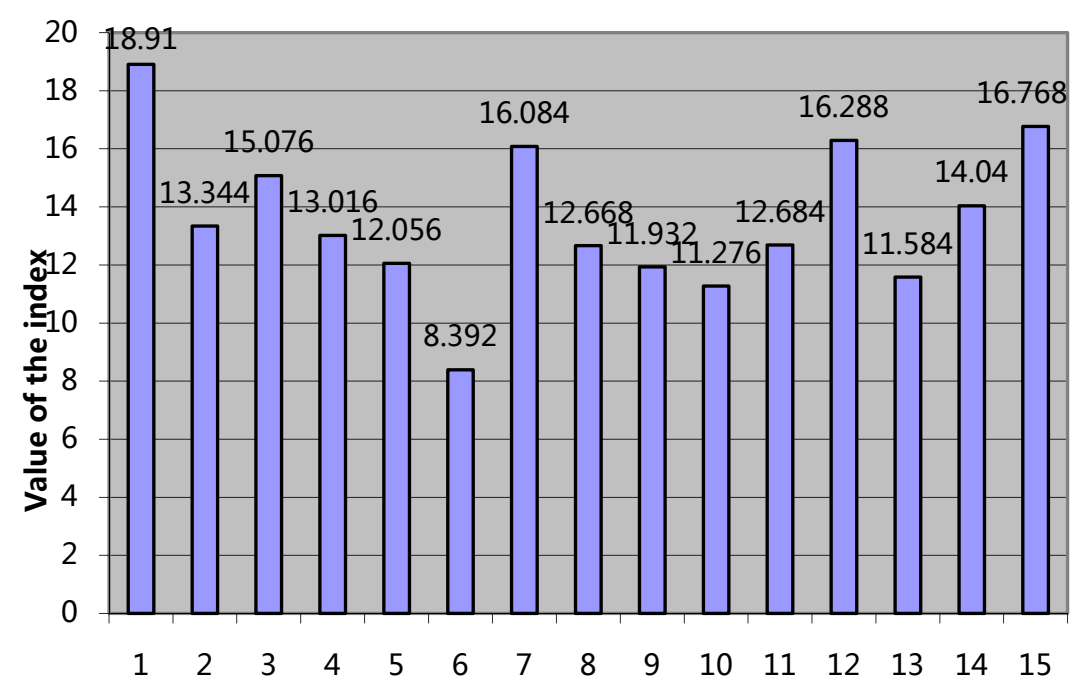

where:

1. - The maximum

2-15. - Regions of the Russian Federation from the total sample.

Figure 1. Levels of performance indicator of the state information support

Thus, the difference in the level of this indicator in the Russian regions is clearly shown, and it allows to evaluate the size of the reserves that are available in the state support system of SE, and the difference between the highest possible level of performance and the actual level in every region of the sample.

Correlation and regression analysis revealed the connection indicator of the effectiveness of public information support to the value of SE final indicators - the innovative activity of organizations, the number of registered small businesses in the region.

For the quantitative assessment of closeness of connection between the indicators used the correlation coefficient (r).

To calculate quantitatively the closeness of the connection we used the Cheddok's scale (Table 2).

Table 2. The characteristic of connection between indicators

\begin{tabular}{lllllll}
\hline The index of closeness connection & $0.1-0.3$ & $0.3-0.5$ & $0.5-0.7$ & $0.7-0.8$ & $0.9-0.99$ & 1 \\
\hline The characteristic of connection & weak & moderate & noticeable & tight & Very tight & functional \\
\hline
\end{tabular}

To test the significance of the coefficient found checking for significance using Student's t test.

The correlation coefficient was 0.7343 , therefore, the association is considered as strong. Student criterion at the confidence level $\mathrm{P}=0.95$ exceeded the table value and was equal to 2,004, indicating the significance of the coefficient.

The coefficient of determination is 0.539 and indicates that $53.9 \%$ of the variation is determined by changes in the effective index of the state of information support.

Regression model under these conditions is as follows:

$$
y=1.18 x-4.9
$$

where $\mathrm{x}$ - the effectiveness of public information support for SEs; $\mathrm{y}$ - the innovative activity of organizations in the region.

Correlation and regression analysis allowed us to identify dependencies and develop models describing influence the effectiveness of different directions of state support of SEs on the number of registered small businesses in the region (per 100 thousand inhabitants).

In this study, models reflecting the relationship between other indicators of assess of state support of SEs and outcome indicators were also drawn up.

\section{Results}

The analysis results are shown in Table 3 and Table 4. 
Table 3. Characteristics of the relationship between the value of innovation activity of organizations in the region and performance indicators of the state support of SE sector

\begin{tabular}{|c|c|c|c|c|c|}
\hline Indicators & $\begin{array}{c}\text { The } \\
\text { correlation } \\
\text { coefficient }\end{array}$ & $\begin{array}{l}\text { The } \\
\text { characteristic } \\
\text { of connection }\end{array}$ & $\begin{array}{l}\text { The Student's } \\
\text { coefficient }\end{array}$ & $\begin{array}{c}\text { The } \\
\text { coefficient of } \\
\text { determination }\end{array}$ & $\begin{array}{c}\text { The regression } \\
\text { model }\end{array}$ \\
\hline $\begin{array}{l}\text { The effectiveness of } \\
\text { information support }\end{array}$ & 0.711 & tight & 2.004, signif. & 0.51 & $y=1.167 x-4.6$ \\
\hline $\begin{array}{l}\text { Availability of state } \\
\text { support programs }\end{array}$ & 0.396 & noticeable & 0.157 , insignif. & - & - \\
\hline $\begin{array}{l}\text { The effectiveness of staff } \\
\text { support }\end{array}$ & 0.872 & tight & 2.28 , signif. & 0.76 & $y=7.95 x-13.33$ \\
\hline $\begin{array}{l}\text { Availability of innovation } \\
\text { infrastructure }\end{array}$ & 0.152 & weak & 0.52 , insignif. & - & - \\
\hline $\begin{array}{l}\text { The effectiveness of the } \\
\text { services provided by } \\
\text { innovation infrastructure }\end{array}$ & 0.882 & tight & 2.289, signif. & 0.774 & $y=0.88 x-2.8$ \\
\hline $\begin{array}{l}\text { Effectiveness of the legal } \\
\text { support }\end{array}$ & 0.763 & tight & 2.103, signif. & 0.58 & $y=5.89 x-5.21$ \\
\hline $\begin{array}{l}\text { The effectiveness of } \\
\text { marketing support }\end{array}$ & 0.716 & tight & 2.02, signif. & 0.51 & $y=7.915 x-11.56$ \\
\hline $\begin{array}{l}\text { The effectiveness of } \\
\text { scientific support }\end{array}$ & 0.684 & moderate & 1.95 , signif. & 0.47 & $y=3.72 x+3.7$ \\
\hline $\begin{array}{l}\text { The effectiveness of } \\
\text { expert and consulting } \\
\text { support }\end{array}$ & 0.816 & tight & 2.19 , signif. & 0.67 & $y=14.14 x-19.45$ \\
\hline $\begin{array}{l}\text { The effectiveness of the } \\
\text { organization } \\
\text { interaction with big } \\
\text { business }\end{array}$ & 0.648 & moderate & 1.884 , signif. & 0.42 & $y=3.72 x+0.375$ \\
\hline $\begin{array}{l}\text { The effectiveness of } \\
\text { financial and credit } \\
\text { support }\end{array}$ & 0.6002 & moderate & 1.78 , signif. & 0.36 & $y=2.66 x-10.25$ \\
\hline
\end{tabular}


Table 4. Characteristics of dependency between the number of registered small businesses (per 100 thousand inhabitants) in the region and the performance indicators of the sector of state support of small innovative business

\begin{tabular}{|c|c|c|c|c|c|}
\hline Indicators & $\begin{array}{c}\text { The } \\
\text { correlation } \\
\text { coefficient }\end{array}$ & $\begin{array}{c}\text { The } \\
\text { characteristic } \\
\text { of connection }\end{array}$ & $\begin{array}{c}\text { The Student's } \\
\text { coefficient }\end{array}$ & $\begin{array}{c}\text { The coefficient } \\
\text { of } \\
\text { determination }\end{array}$ & The regression model \\
\hline $\begin{array}{l}\text { The effectiveness of } \\
\text { information support }\end{array}$ & 0.628 & moderate & 1.845, signif. & 0.39 & $y=13.88 x-34.42$ \\
\hline $\begin{array}{l}\text { Availability of state } \\
\text { support programs }\end{array}$ & 0.86 & tight & 2.259, signif. & 0.74 & $y=74.5 x-112.3$ \\
\hline $\begin{array}{l}\text { The effectiveness of } \\
\text { staff support }\end{array}$ & 0.216 & weak & 0.73 , insignif. & - & - \\
\hline $\begin{array}{l}\text { Availability of } \\
\text { innovative infrastructure }\end{array}$ & 0.898 & tight & 0.81 , signif. & 0.81 & $y=70.68 x-59.1$ \\
\hline $\begin{array}{l}\text { The effectiveness of the } \\
\text { services provided by } \\
\text { innovation } \\
\text { infrastructure }\end{array}$ & 0.158 & weak & 0.54 , insignif. & - & - \\
\hline $\begin{array}{l}\text { Effectiveness of the } \\
\text { legal support }\end{array}$ & 0.445 & weak & 1.41, insignif. & - & - \\
\hline $\begin{array}{l}\text { The effectiveness of } \\
\text { marketing support }\end{array}$ & 0.628 & moderate & 1.845 , signif. & 0.39 & $y=93.45 x-115.26$ \\
\hline $\begin{array}{l}\text { The effectiveness of } \\
\text { scientific support }\end{array}$ & 0.494 & noticeable & 1.52, insignif. & - & - \\
\hline $\begin{array}{l}\text { The effectiveness of } \\
\text { expert and consulting } \\
\text { support }\end{array}$ & 0.49 & noticeable & 1.524, insignif. & - & - \\
\hline $\begin{array}{l}\text { The effectiveness of the } \\
\text { organization of } \\
\text { interaction with big } \\
\text { business }\end{array}$ & 0.727 & tight & 2.04, signif. & 0.53 & $y=56.16 x-8.77$ \\
\hline $\begin{array}{l}\text { The effectiveness of } \\
\text { financial and credit } \\
\text { support }\end{array}$ & 0.602 & moderate & 1.79 , signif. & 0.362 & $y=35.88 x-135.2$ \\
\hline
\end{tabular}

This is the process of improving the use of a set of directions of state information support for SE in general form (see Fig. 2). 


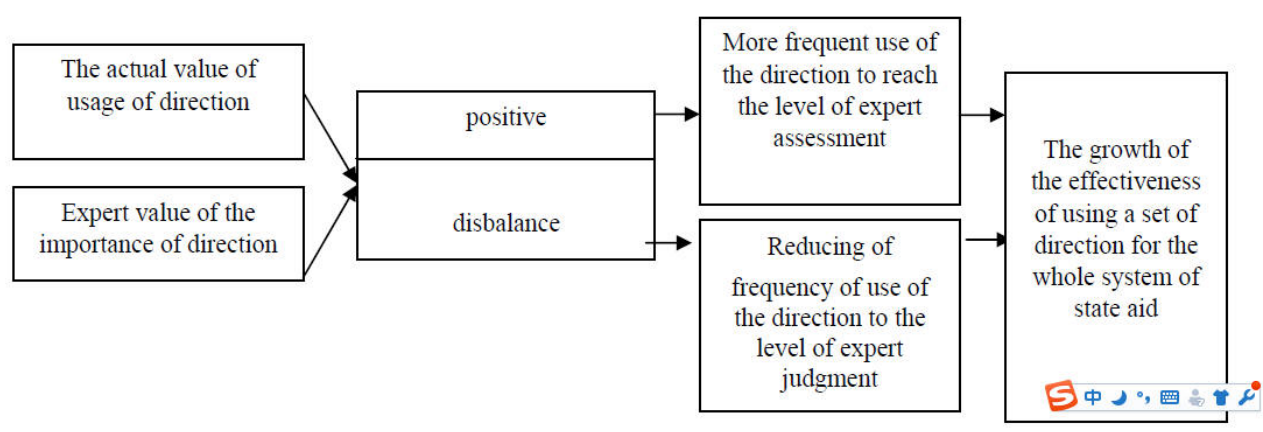

Figure 2. Diagram of improving the use of a set of support directions

Thus, we developed a method that allows to quantify the existing level of quality processes (directions) sector management SEs in the region, and to identify existing reserves in the state aid system.

In addition proposed correlation and regression models describing the effect of the individual processes (directions) on the effectiveness of state management system of SE as a whole. Using of these models in the practice of public sector management allows take into account the impact qualitative factors in evaluating the effectiveness of public administration to small innovative business in Russia.

\section{Discussion}

Russian and foreign researchers in innovations pay significant attention to development of approaches, methodologies, tools and mechanisms to evaluate the efficiency of state aid to SE. Vast majority of researchers offer to use only quantitative indicators to estimate the effectiveness. Nevertheless, this approach does not allow taking into account a number of factors that contribute to the shaping and development of innovative activity of the SEs. It is insufficient without using of expert evaluations and sociological research in this issue.

Having determined the key factors that have strong influence on the effectiveness of state support system, we obtained a possibility of rational distribution of resources for its operation and development.

Identified dependence needs to be periodically corrected, that is not particularly difficult.

Thus, the authors have developed a method of evaluating the effectiveness of the system of state support at the regional level, which makes it possible to assess the actual level of performance management in a particular region and to identify existing reserves. Correlation and regression analysis, which allows to identify the most important factors have strong influence on the effectiveness of the state support system in the sector. Also proposed correlation and regression models (for example, the model showing the influence of the effectiveness of information support for innovative activity of organizations in the region; model showing the influence of accessibility of innovative infrastructure on the number of small businesses in the region, per 100 thousand inhabitants, and others). Application of this method in the practice of public administration small innovative business sector will take into account the influence of qualitative factors in evaluating the effectiveness of the system as a whole.

\section{Conclusions}

Thus, the proposed method allows us:

1) To evaluate the actual level of development of individual management directions of state support for SEs in specific regions of the country;

2) To conduct a comparative analysis of the levels of each of the directions of state regional control system to determine the leading regions, lagging behind and occupy an intermediate position for each indicator the efficiency of state support system for SE;

3) To compare the actual level of the individual indicator of the effectiveness of state support with the greatest possible value, which identifies the available reserves in management system of SE.

The conclusion that follows from the results of the study allows management authorities to focus on the directions of state support system, but it doesn't mean ignoring the other indicators because only integrated management will ensure the maximum efficiency. 
The detailed examination of the whole support system for SE and innovative features of its future development provides the possibilities to make a forecast of development management system based on the proposed correlation and regression models. However, it is impossible to take into account the factor of sharp changes in the external environmental conditions.

The study developed the methods with the following characteristics:

Firstly, the proposed methodological approach allows the inclusion of new directions of support, reflecting its flexibility and high adaptive capacity.

Secondly, it is possible to take into account the territorial features of the regions in which the research of effectiveness of state support system is conducted.

Thirdly, the technique allows to identify existing reserves of development, to identify key factors which have strong influence on the efficiency of state support system, combined in the territorial basis, and to make a comparison between objects of the research.

However, presented technique is limited by conditions of its application in practice:

- Set of factors and their relevance (weighting factors) will vary by region where appropriate analysis will conducted.

- Data sources should be sufficient to a finding of weighting factors and identify trends.

- Revealed relations should be sufficiently stable during a given period.

In addition, the future perspective of using the proposed method is making forecasting results based on mathematical models, but it is adequate only in the medium term.

\section{References}

Avery, R. B., Bostic, R. W., \& Samolyk, K. A. (1998). The Role of Personal Wealth in Small Business Finance. Journal of Banking and Finance, 22(6-8), 1019-1061. http://dx.doi.org/10.1016/s0378-4266(98)00016-8

Baranova, I. V. (2009). Evaluation of municipal target programs of development and support of small business. Finance and Credit, 25, 40-46.

Berger, A. N., \& Udell, G. F. (1998). The economics of small business finance: The roles of private equity and debt markets in the financial growth cycle. Journal of Banking and Finance, 22(6/8), 613-673. http://dx.doi.org/10.1016/s0378-4266(98)00038-7

Cefis, E., Ghita, M., \& Sabidussi, A. (2009). Partnerships and innovative patterns in small and medium enterprises. International Journal of Entrepreneurship and Small Business, 4, 431. http://dx.doi.org/10.1504/ijesb.2009.023360

Dadashov, A. et al. (2002). The effectiveness of small business support. Problems of Economics, 7, 109-118.

Duplenko, N. G. (2012). Development of small innovative entrepreneurship through the harmonization of economic interests. Baltijskij region, 3, 34-46. http://dx.doi.org/10.5922/2074-9848-2012-3-2

Federal State Statistics. (2015). Federal State Statistics. Service Innovations. Retrieved from http://www.gks.ru//wps/wcm/connect/rosstat_main/rosstat/ru/statistics/science_and_innovations/science/\#

Fuller, T. (2005). SME local clusters and support policies. Environment and Planning C: Government and Policy, 6, 795-797. http://dx.doi.org/10.1068/c2306ed

Gamidullaeva, L. A. (2014). Problems and prospects of Russia's economy modernization. Fundamental research, $11,2010-2015$.

Gamidullaeva, L. A. (2015). Modeling of Innovation Cluster Management System. Creative Economy, 2(98), 225-236.

Garifullina, E. F. (2014). Development of human capital as an innovative direction of public policy. Economy, trends and management, 2, 36-43. http://dx.doi.org/10.7256/2306-4595.2014.2.4544

Generalov, V. V., \& Lychagin, M. V. (2004). Analysis of the programs of state support of entrepreneurship. Novosibirsk, N: Novosibirsk State University.

Gregory, B. T., Rutherford, M. W., Oswald, S., \& Gardiner, L. (2005). An empirical investigation of the growth cycle theory of small firm financing. Journal of Small Business Management, 43(4), 382-392. http://dx.doi.org/10.1111/j.1540-627x.2005.00143.x 
Gromova, N. M., \& Gromova, N. I. (2006). Foundations of Economic Forecasting. Moscow: Academy of Natural Sciences.

Handbook on community state aid rules for SMEs. (2009). Retrieved from http://ec.europa.eu/competition/state_aid/studies_reports/sme_handbook.pdf

Hübner, D. (1996). Small Business in Transition Economies. Practical Action Publishing Chapter. http://dx.doi.org/10.3362/9781780440941.002

Justman, M., \& Teubal, M. (1996). Technological Infrastructure Policy (TIP): An International Perspective. Dordrecht: Kluwer International Publishers. http://dx.doi.org/10.1007/978-94-015-8739-6_2

Kalmykova, A. et al. (2014). Industrial parks infrastructure innovation. M.: Infra-M Academic Publishing House. http://dx.doi.org/10.12737/2840

Karwowska, M. A., \& Mrozinska, E. (1993). Policy Support for SMEs in Poland. International Small Business Journal, 1, 61-69. http://dx.doi.org/10.1177/0266242693121004

Lorrain, J., \& Laferté, S. (2006). Support Needs of the Young Entrepreneur. Journal of Small Business \& Entrepreneurship, 1, 37-48. http://dx.doi.org/10.1080/08276331.2006.10593357

Lukyanov, G. A., \& Avanesova, R. F. (2011). Some questions and methodology for evaluating the performance of small businesses in the regional economy. Kant. 2. Retrieved from http://cyberleninka.ru/article/n/nekotorye-voprosy-metodologii-i-otsenki-effektivnosti-funktsionirovaniyamalogo-biznesa-v-regionalnoy-ekonomike

Mcmahon, R. G. P. (1990). Expert Systems and Financial Decision Support in Small Businesses. International Small Business Journal, 2, 23-33. http://dx.doi.org/10.1177/026624269000800202

Norrman, C., \& Bager-Sjogren, L. (2010). Entrepreneurship policy to support new innovative ventures: Is it effective? International Small Business Journal, 6, 602-619. http://dx.doi.org/10.1177/0266242610369874

Russian Federal State Statistics Service. (2015). Retrieved from http://www.gks.ru

Savanovich, A. V. (2009). The concept of management of regional infrastructure development of small innovative business. Vestnik Immanuel Kant Baltic Federal, 3, 105-111. http://dx.doi.org/10.5922/2223-2095-2009-3-16

Siu, W. (1996). An innovative approach to designing a mail survey for small firms. Journal of Small Business \& Entrepreneurship, 3, 86-95. http://dx.doi.org/10.1080/08276331.1996.10600531

Stark, N., \& Brown, H. (1997). Harvesting Hometown Jobs: The New Small Guide to Local Economic Development. Washington, DC: The National Center for Small Communities (NCSC). http://dx.doi.org/10.1897/1551-5028(1997)016\%3C2494:ctofii\%3E2.3.co;2

Vasin, S. M. (2012). The nature and essence of the concept of management system effectiveness. Vector of science of Togliatti State University, 4, 229-233. Retrieved from $\mathrm{http} / / /$ cyberleninka.ru/article/n/priroda-i-suschnost-ponyatiya-effektivnosti-sistemy-upravleniya-predpriyati em

Vasin, S. M., \& Gamidullaeva, L. A. (2015). Methodical approach to the assessment of organizational capacity higher education institutions. Regional economy: Theory and practice, 13(388), 16-28.

Vasin, S. M., \& Gamidullaeva, L. A. (2015). Methodical Approach and Tools to Improve the Efficiency of Managing of the Innovation Potential in the Context of Economic Globalization. Review of European Studies, 3, 124-140. http://dx.doi.org/10.5539/res.v7n3p124

Vasin, S. M., \& Gamidullaeva, L. A. (2014). The Development of the Assessment Methods of the Organizational Potential of the Institutions of High Education. Asian Social Science, 24, 285-296. http://dx.doi.org/10.5539/ass.v10n24p285

Vasin, S. M., \& Gamidullaeva, L. A. (2015). Modeling and Development of a Methodology for Assessing the Socio-Economic Processes in the Management of Business Incubators. Mediterranean Journal of Social Sciences, 3, 212-220. http://dx.doi.org/10.5901/mjss.2015.v6n3p212 


\section{Copyrights}

Copyright for this article is retained by the author(s), with first publication rights granted to the journal.

This is an open-access article distributed under the terms and conditions of the Creative Commons Attribution license (http://creativecommons.org/licenses/by/3.0/). 